\title{
CUKA AREN (Arenga pinnata): KAJIAN PEMANFAATAN OLEH INDIGENOUS PEOPLE KAMPUNG ADAT KUTA BERDASARKAN FLOK KNOWLEGDE
}

\author{
Reza Fauzi Dwisandi' ${ }^{1}$, Diana Hernawati' ${ }^{2}$, Egi Nuryadin ${ }^{3)}$ \\ 1,2,3) Universitas Siliwangi Tasikmalaya \\ Email: ${ }^{1)}$ rezafauzidwisandi@gmail.com ${ }^{1)}$, 2)hernawatibiologi@unsil.ac.id, ${ }^{3)}$ egi.nuryadin@unsil.ac.id
}

Diterima 2 Februari 2021 disetujui 13 April 2021 diterbitkan 15 Mei 2021

\begin{abstract}
Palm vinegar is one of the processed products from a type of plant from the Arecaceae family, namely Arenga pinnata. Arenga vinegar is used by the people of the Kuta traditional village as a traditional medicine to treat a disease or prevent disease, this is based on folk knowledge, experience and ancestral traditions passed down from generation to generation in using plants as medicine. However, their utilization practices have not been published, identified and documented. Therefore, this study aims to describe the stages of making arenga vinegar and the practice of using it as a traditional medicine in Kuta Traditional Village. This research was conducted in Kuta Traditional Village, Tambak Sari District, Karangpaninggal Village, Ciamis Regency, in January-February 2021. This research is qualitative research study using the phenomenological method, the data collection technique used in this study are passive participation and active participation observation, semistructured interviews with 4 people, namely 3 men and 1 woman, and document studies were carried out. The results showed that the arenga vinegar making stages in Kuta Traditional Village includes the process of lodong sterilizer, tapping arenga juice, filtering arenga juice, storing and fermenting arenga juice. As for its use, arenga vinegar is believed to be a traditional medicine such as types of fever, aches, liver, diabetes, stomach acid and external wounds.
\end{abstract}

Keywords: Arenga Vinegar, Folk Knowledge, Medical Ethnobotany

\section{PENDAHULUAN}

Indonesia memiliki keanekaragam hayati flora yang beragam, hal tersebut merupakan aset jangka panjang yang berharga sehingga perlu dikaji, diteliti, dan dimanfaatkan oleh kita sebagai pemilik bangsa ini. Keanekaragaman hayati flora tersebut mencapai 20.000 species, sehingga diperkirakan species tumbuhan berbunga yang ada di dunia ini sebanyak 25\%-nya berasal dari Indonesia (Kusmana \& Hikmat, 2015). Keanekaragaman hayati flora yang dimiliki Indonesia ini berpengaruh terhadap berbagai aspek kehidupan masyarakatnya yang kaya juga akan keanekaragaman budayanya (Rintelen, Arida, \& Häuser, 2017). Hal tersebut menjadikan pengalaman serta keyakinan setiap masyarakat di Indonesia berbeda-beda dalam pemanfaatan keanekaragaman hayati flora yang dimilikinya.

Praktik pemanfaatan keanekaragam hayati flora ini, biasanya dilakukan oleh masyarakat lokal dibeberapa suku di Indonesia yang memiliki pengetahuan (folk knowledge) terkait pengobatan tradisional serta masih menjaga tradisi leluhur dalam memanfaatkan tanaman sebagai obat untuk mengobati suatu penyakit maupun mencegah penyakit (Situmorang \& Sihombing, 2018). Namun, selama ini praktik pemanfaatan tumbuhan obat oleh masyarakat lokal belum banyak terpublikasi, teridentifikasi, dan terdokumentasi. Faktanya, sekitar 6000 species tumbuhan telah dimanfaatkan oleh masyarakat Indonesia sebagai obat-obatan herbal secara tradisional, namun yang terdaftar resmi di Badan Pengawas Obat dan Makanan (BPOM) hanya sebanyak 283 
species tumbuhan (Elfahmi, Woerdenbag, \& Kayser, 2014).

Pemanfaatan jenis tanaman Arecaceae (palem-paleman), turut menjadi kepercayaan masyarakat lokal dalam kehidupan sehari-hari sebagai sumber tanaman obat (Nuryanti, Linda, \& Lovadi, 2015). Salah satunya oleh masyarakat Kampung Adat Kuta, Kecamatan Tambak Sari, Desa Karangpaninggal, Kabupaten Ciamis yang memanfaatkan air kelapa (Cocos nucifera) sebagai pengobatan tradisional seperti obat sakit perut, pelancar buang air kecil, penghilang dehidrasi, pengurang rasa mual saat hamil dan pengurang rasa nyeri saat haid (Ryandita, Hernawati, \& Putra, 2020).

Selain itu, tanaman Arecaceae lain yang dimanfaatkan oleh masyarakat Kampung Adat Kuta, yakni nira aren (Arenga pinnata) yang dapat diolah menjadi gula aren, wedang dan cuka aren. Salah satu produk yang digunakan untuk pengobatan tradisional yakni cuka aren hasil fermentasi. Hal tersebut perlu diteliti lebih lanjut, karena proses pembuatan cuka aren untuk dijadikan sebagai pengobatan tradisional tersebut merupakan salah satu tradisi kebudayaan masyarakat Kampung Adat Kuta yang menjadi bentuk kelangsungan hidup masyarakat itu sendiri, sehingga perlu dilestarikan (Firmansyah \& Putrisari, 2017).

Kajian pemanfaatan tumbuhan lokal untuk tujuan pengobatan tersebut merupakan studi etnobotani tumbuhan obat. Etnobotani obat merupakan hubungan antara individu atau kelompok tradisional dalam penggunaan flora lokal untuk tujuan pengobatan, yang hubungannya erat dengan

\section{HASIL DAN PEMBAHASAN}

Berdasarkan hasil penelitian

1. Tahapan Pembuatan Cuka Aren di Kampung Adat Kuta

a. Pemuputan Lodong

Petani aren di Kampung Adat Kuta biasa mensterilkan lodong bekas penyadapan sebelumnya dengan istilah kandungan senyawa kimia yang terdapat di dalamnya (Albuquerque \& Alves, 2016). Adapun penelitian ini, bertujuan untuk mendeskripsikan tahapan pembuatan cuka aren serta praktik pemanfaatannya sebagai obat tradisional di Kampung Adat Kuta Kabupaten Ciamis.

\section{METODE}

Penelitian ini dilakukan di Kampung Adat Kuta, Kecamatan Tambak Sari, Desa Karangpaninggal, Kabupaten Ciamis. Teknik pengumpulan data yang digunakan dalam penelitian ini yakni observasi partisipasi pasif dan partisipasi aktif, wawancara semi-terstruktur kepada informan kunci dengan jumlah informan sebanyak 4 orang, yaitu 3 orang pria dan 1 orang wanita untuk menggali kepercayaan masyarakat Kampung Adat Kuta mengenai pemanfaatan cuka aren yang dapat digunakan sebagai pengobatan tradisional, serta dilakukan dokumentasi pengamatan pembuatan cuka aren serta praktik pemanfaatannya yang biasa dilakukan oleh masyarakat adat Kampung Kuta (Hasanah, 2017; Sugiyono, 2016).

Penelitian ini dilaksanakan pada bulan Januari-Februari 2021. Jenis penelitian yang digunakan dalam penelitian ini yakni penelitian kualitatif dengan menggunakan pendekatan fenomenologi untuk menyelidiki fenomena masyarakat adat Kampung Kuta dalam memanfaatkan cuka aren sebagai pengobatan tradisional. Teknik analisis data menggunakan model Miles and Huberman meliputi reduksi data, penyajian data dan penarikan kesimpulan/verifikasi (Sugiyono, 2016).

"dipuput", yakni dengan memasukan lodong bekas pemakaian ke dalam bambu puputan yang ukurannya lebih panjang dan kecil, bambu puput tersebut ditumpangkan pada lubang hawu puputan, dapat dilihat pada gambar 1. Sterilisasi dengan cara tradisional tersebut menggunakan hawa panas yang masuk ke dalam bambu puputan dan terperangkap pada ujung 
Florea : Jurnal Biologi dan Pembelajarannya, 8(1), 2021, 1-11

This is an open access article under the CC-BY-SA license (https://creativecommons.org/licenses/by-sa/4.o/) ISSN 2355-6102(print), ISSN 2502-0404(online)

DOI : 10.25273/florea.v8i1.8913

lodong atau dasar lodong, sehingga menyebabkan udara dalam lodong panas. Semakin besar api pada hawu puputan maka lodong akan cepat panas sehingga mempercepat proses sterilisasi, artinya besar api mempengaruhi lama atau tidaknya proses sterilisasi. Tujuan petani aren memuput lodong ini supaya lodong terbebas dari kotoran sehingga tidak menyebabkan air nira yang tertampung nantinya cepat masam, sehingga air nira akan berkualitas baik dan wangi. Proses pemuputan ini, jika ditinjau dalam skala laboratorium maka termasuk ke dalam proses sterilisasi metode panas kering yang biasanya menggunakan alat sterilisator panas kering, tujuannya untuk membunuh kuman patogen pada alat laboratorium yang disterilisasi (Raudah, Zubaidah, \& Santoso, 2017; Yudianti, Suprapti, \& Hupitoyo, 2015).

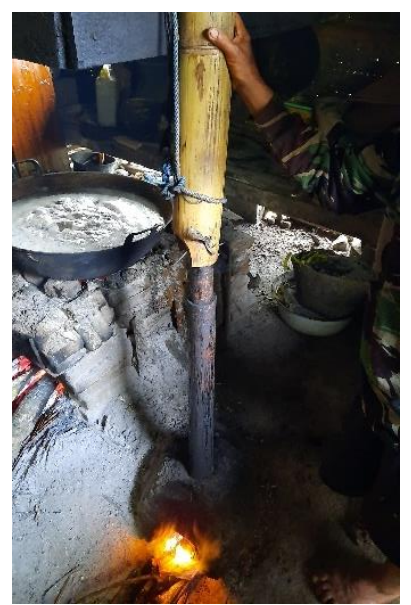

Gambar 1. Proses sterilisasi lodong menggunakan puputan

b. Penyadapan Air Nira

Sebelum melakukan proses penyadapan air nira, petani aren di Kampung Adat Kuta biasa memasukan raru ke dalam lodong yang telah dipuput yang akan digunakan dalam proses penyadapan. Raru ini merupakan istilah untuk nama benda berbahan organik dari tanaman yang bertujuan sebagai pengawet yang dapat mencegah terjadi keasaman pada tampungan air nira ketika proses penyadapan berlangsung. Raru di Kampung Adat Kuta terbuat dari satu tangkai daun ginggiyang (Leea sp.) yang sedikit diremas- remas lalu digulung-gulung membentuk bulatan dan dikunci mati, dapat dilihat pada gambar 2. Tujuan raru berbentuk bulat yakni supaya raru di dalam tampungan dapat berputar ketika terkena tetesan air nira, adapun jumlah raru yang dimasukan ke dalam lodong yakni satu buah.

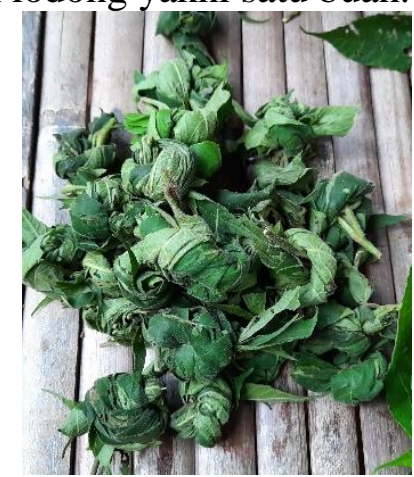

Gambar 2. Raru dari pohon ginggiyang (Leea sp.)

Arti dari raru yakni obat yang merupakan bahan pengawet alami yang berasal dari daun-daunan yang diremasremas dan digelang-gelang lalu dimasukan ke dalam lodong bambu, adapun daun yang dapat digunakan sebagai bahan raru yakni daun togog (famili Moraceae), daun jambu air (Syzigium aquea Burn.f.), daun manggis (Garcinia mangostana L.) dan pucuk bambu tali (Gigantochloa apus). Raru tersebut diduga mengandung senyawa tanin sebagai antimikroba (Irawan, Rahmayani, \& Iskandar, 2009; Natawijaya, Suhartono, \& Undang, 2018) Senyawa tanin dapat bersifat sebagai antibakteri sehingga mampu menghambat pertumbuhan bakteri (Mufti, Bahar, \& Arisanti, 2017).

Petani aren di Kampung Adat Kuta, biasanya melakukan proses penyadapan pada dini hari yakni antara pukul 05.0007.00 WIB dan pada sore hari yakni antara pukul 15.00-17.00 WIB. Pohon aren yang sudah bisa disadap adalah pohon aren yang sudah berusia puluhan tahun dan sudah menghasilkan banyak bunga betina (caruluk) maupun bunga jantan (langari). Menurut pernyataan Adeng et al., (2014) bahwa pohon aren yang sudah siap disadap jika pohon aren sudah memiliki 4-5 tangkai bunga betina (caruluk) dan 1-2 tangkai bunga jantan (langari). Adapun bunga yang disadap di Kampung Adat Kuta yakni 
Florea : Jurnal Biologi dan Pembelajarannya, 8(1), 2021, 1-11

This is an open access article under the CC-BY-SA license (https://creativecommons.org/licenses/by-sa/4.o/) ISSN 2355-6102(print), ISSN 2502-0404(online)

DOI : 10.25273/florea.v8i1.8913

tangkai bunga jantan (langari) yang sudah ditinggur atau dipukul-pukul sebelumnya untuk merangsang air nira keluar untuk pertama kalinya, namun untuk proses selanjutnya hanya dilakukan proses pemagasan menggunakan pisau sadap.

Penyimpanan lodong bambu yang berisi raru di dalamnya pada proses penyadapan dilakukan selama kurang lebih 12 jam dan menghasilkan jumlah air nira yang tidak menentu, terkadang penuh satu lodong atau hanya setengahnya. Jika penyadapan dilakukan pada pagi hari, maka lodong yang telah berisi air nira diambil dan diganti pada sore hari, begitupun sebaliknya.

Adapun proses penyadapan air nira tersaji pada gambar 3 .

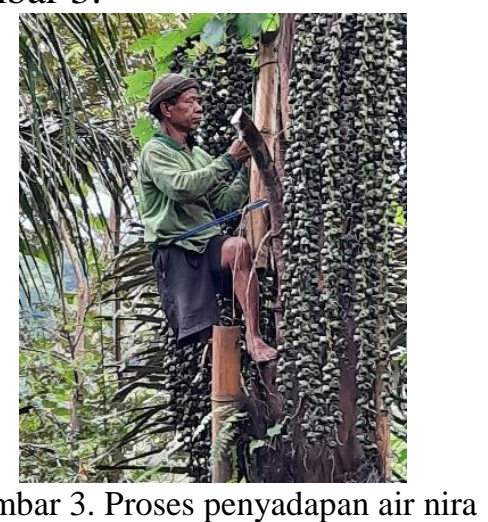

\section{c. Penyaringan Air Nira}

Air nira yang telah didapatkan sebelum dijadikan olahan produk berupa cuka aren, diperlukan proses penyaringan guna membersihkan air nira dari kotoran dan benda asing yang masuk ke dalam lodong, dapat dilihat pada gambar 3 . Adapun kotoran dan benda asing yang tersaring yakni bubudur atau buih air nira, raru bekas, serta serangga-serangga meliputi lebah madu (Apis sp.), kumbang (Ordo Coleoptera) dan semut (Famili Formicidae), untuk pembuatan cuka aren maka air nira yang telah disaring tersebut kemudian dimasukkan ke dalam botol guna dilakukan proses fermentasi.

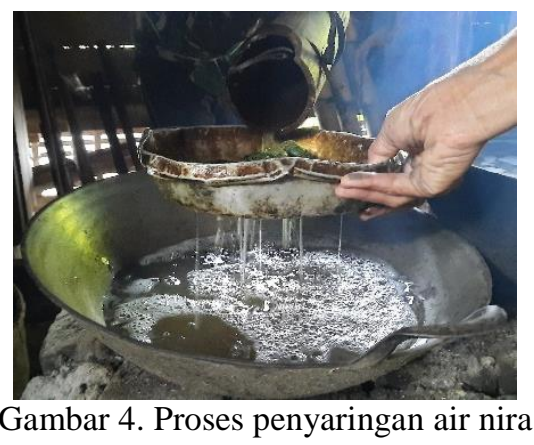

d. Penyimpanan dan Fermentasi Air Nira

Hasil pengujian air nira secara organoleptik sebelum difermentasikan yakni berwarna coklat terang, beraroma wangi khas aren, rasanya manis dan segar dengan nilai $\mathrm{pH}$ sebesar 6 .

Pembuatan cuka aren di Kampung Adat Kuta dilakukan dengan cara fermentasi pembuatan alkohol aren terlebih dahulu, lalu dengan sendirinya berubah menjadi cuka, dan dikenal dengan istilah "dipoe diibun" yang artinya dijemurkan dan diembunkan. Sejalan dengan pendapat Lempang, (2012) bahwa cuka diperoleh melalui proses fermentasi dari nira aren, yang lama-kelamaan berubah menjadi alkohol, lalu akan terurai dan terbentuk menjadi cuka atau asam asetat.

Adapun tahapan pertama dalam proses pembuatan cuka di Kampung adat Kuta yakni dengan menggunakan botol yang ditutup rapat sehingga tidak ada udara luar yang masuk, dan tidak boleh dibuka selama tiga hari. Masyarakat Kampung Adat Kuta biasa menyimpan botol air nira tersebut dengan empat cara di tempat yang berbeda, yakni dengan cara menyimpannya di atas palang dada saung atau di atas songgo tanaman, menggantungkannya pada jemuran pakaian serta menguburkannya ke dalam tanah sedalam tinggi botol tersebut, dapat dilihat pada gambar 5 . 


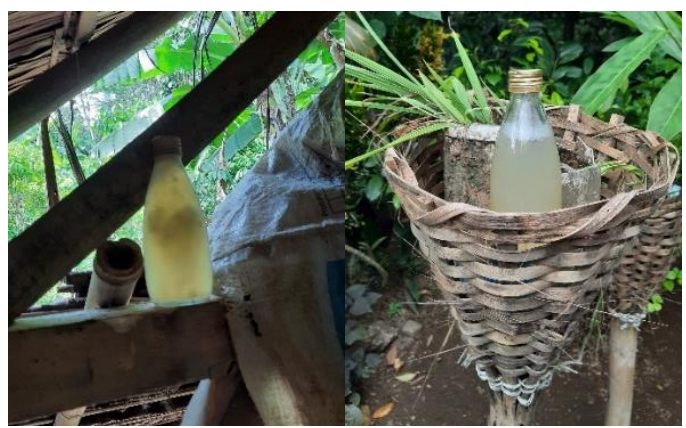

(a)

(b)

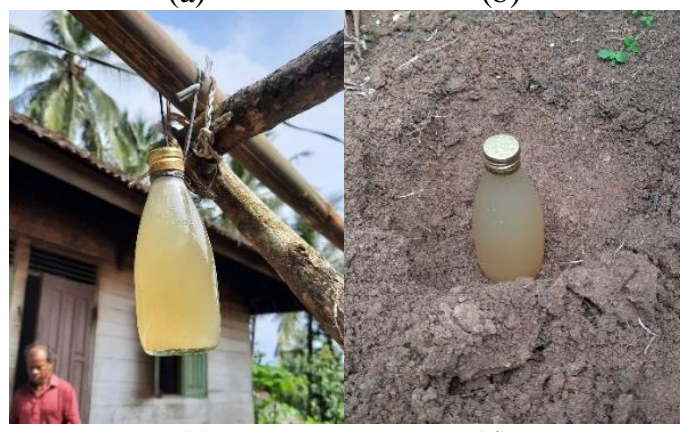

(c)

(d)

Gambar 5. Penyimpanan air nira dalam proses fermentasi (a) Disimpan di atas palang dada saung (b) Disimpan di atas songgo tanaman (c) Digantung di jemuran pakaian (d) Dikubur di dalam tanah

Perbedaan empat cara penyimpanan tersebut memiliki tujuan yang berbedabeda, yakni :

- Penyimpanan botol air nira di atas palang dada saung, bertujuan supaya air nira tidak terpapar sinar matahari secara langsung, sehingga tidak menyebabkan air nira terlalu panas karena hanya menyerap hawa panas dari bawah atap ijuk saung.

- Penyimpanan botol air nira di atas songko tanaman dan digantung di jemuran pakaian, bertujuan supaya air nira terpapar sinar matahari secara langsung, sehingga air nira cepat panas, namun jika panas matahari terlalu terik biasanya masyarakat memindahkannya ke tempat teduh terlebih dahulu.

- Penyimpanan botol air nira yang dikubur di dalam tanah sedalam tinggi botol tersebut, bertujuan supaya air nira tidak terpapar sinar matahari langsung, namun terkena hawa panas dari tanah bagian atas dan terkena hawa dingin dari tanah bagian bawah.
Tahapan penyimpanan selama tiga hari tanpa dibuka artinya selama tiga hari tersebut air nira yang disimpan mengalami proses fermentasi alkohol, karena tidak ada gas oksigen $\left(\mathrm{O}_{2}\right)$ yang masuk ke dalam botol, proses fermentasinya dilakukan oleh organisme berupa jamur uniseluler. Sejalan dengan pendapat para ahli bahwa pembuatan alkohol dari air nira dilakukan dalam wadah tertutup (Lempang, 2012), artinya melalui proses anaerobik yang berlangsung dengan bantuan ragi, biasanya di dalam air nira yang digunakan sudah terdapat ragi secara alami yakni Saccharomyces tuac, produk hasil fermentasinya disebut tuak yang mempunyai kadar etanol 4\% (Baharuddin, Syahidah, \& Yatni, 2009).

Bahan utama dari proses fermentasi alkohol pada nira aren yakni glukosa, yang terlebih dahulu mengalami glikolisis atau pemecahan menjadi 2 asam piruvat, 2 ATP dan $2 \mathrm{NADH}$, yang kemudian 2 asam piruvat akan diubah menjadi alkohol melalui dua tahapan yakni yang pertama yaitu pelepasan karbondioksida $\left(\mathrm{CO}_{2}\right)$ sehingga 2 asam piruvat menjadi 2 asetaldehid. Selanjutnya, tahapan yang kedua, bahwa 2 asetaldehid tersebut akan direduksi oleh $2 \mathrm{NADH}$ dan menghasilkan 2 etanol. Adapun tahapan proses fermentasi alkohol tersaji pada gambar 6 .

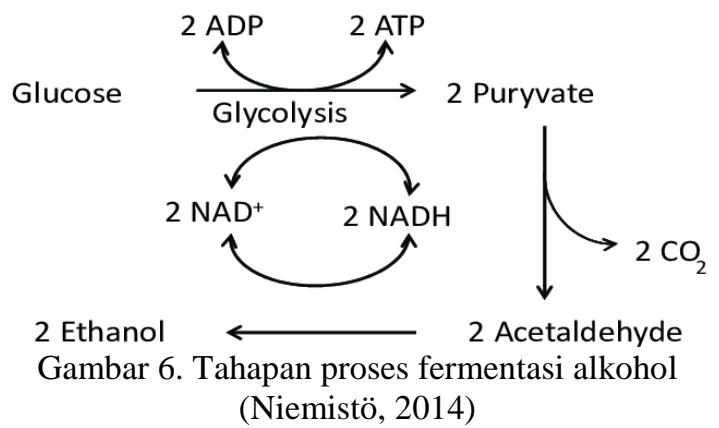

Setelah tiga hari melalui tahapan tersebut, botol harus dibuka dengan tujuan mengeluarkan gas yang dihasilkan oleh alkohol nira hasil fermentasi berupa gas karbondioksida $\left(\mathrm{CO}_{2}\right)$ supaya alkohol nira terpapar udara segar dari luar. Adapun Hasil pengujian alkohol nira secara organoleptik yakni berwarna kuning 
Florea : Jurnal Biologi dan Pembelajarannya, 8(1), 2021, 1-11

This is an open access article under the CC-BY-SA license (https://creativecommons.org/licenses/by-sa/4.o/)

ISSN 2355-6102(print), ISSN 2502-0404(online)

DOI : 10.25273/florea.v8i1.8913

keputihan, beraroma alkohol, rasanya sedikit manis dan agak kecut dengan nilai $\mathrm{pH}$ sebesar 5.

Alkohol nira yang dibiarkan beberapa saat dalam keadaan terbuka, kemudian ditutup dan disimpan kembali, tujuan penutupan oleh masyarakat Kampung Adat Kuta supaya alkohol nira tidak terpapar atau kemasukan benda asing karena sejatinya proses penyimpanan dilakukan di luar rumah, namun alkohol nira tersebut setiap harinya secara berkala dilakukan buka tutup botol secara terus menerus, sehingga udara segar berupa oksigen $\left(\mathrm{O}_{2}\right)$ dari luar tetap bisa masuk, sehingga pembuatan cuka tetap berlangsung dan dilakukan selama 9 hari. Idealnya pembuatan cuka justru dilakukan di dalam wadah terbuka terus menerus (Lempang, 2012), artinya melalui proses aerobik dengan cara oksidasi alkohol menjadi asam asetat yang berlangsung melalui bakteri asam asetat yakni Acetobacter aceti yang sudah terdapat dalam nira tersebut pada saat proses penyadapan, proses fermentasi alkohol dengan dilanjutkan dengan pembuatan cuka, berlangsung selama 8 hari pada suhu optimal yakni $30-35^{\circ} \mathrm{C}$, jika suhu kurang dari $30^{\circ} \mathrm{C}$ maka proses fermentasi akan terhambat, namun jika suhu lebih dari $35^{\circ} \mathrm{C}$ maka bakteri Acetobacter aceti akan mati, dan menyebabkan proses fermentasi tidak akan berlangsung (Baharuddin et al., 2009; Naibaho, Ramadhan, Lisnawati, Rahman, \& Popang, 2017; Sumendap, Pesik, \& Lagarense, 2015).

Pembuatan cuka dalam proses kimianya tidak terjadi fermentasi kembali karena larutan alkohol aren sudah terpapar gas oksigen $\left(\mathrm{O}_{2}\right)$, sehingga yang terjadi yakni proses oksidasi berupa pembentukan senyawa asam asetat dari senyawa etanol, dapat dilihat pada gambar 7. Adapun proses reaksinya yakni etanol $\left(\mathrm{CH}_{3} \mathrm{CH}_{2} \mathrm{OH}\right)$ mengikat $1 / 2$ oksigen $\left(\mathrm{O}_{2}\right)$ dan teroksidasi menjadi asetaldehid $\left(\mathrm{CH}_{3} \mathrm{CHO}\right)$ dan air $\left(\mathrm{H}_{2} \mathrm{O}\right)$, kemudian asetaldehid $\left(\mathrm{CH}_{3} \mathrm{CHO}\right)$ dan $\left(\mathrm{H}_{2} \mathrm{O}\right)$ tersebut mengalami hidrasi menjadi 1,1-etanadiol $\left(\mathrm{CH}_{3} \mathrm{CH}(\mathrm{OH})_{2}\right)$.
Selanjutnya 1,1-etanadiol $\left(\mathrm{CH}_{3} \mathrm{CH}(\mathrm{OH})_{2}\right)$ mengikat $1 / 2$ oksigen $\left(\mathrm{O}_{2}\right)$ dan teroksidasi menjadi asam asetat $\left(\mathrm{CH}_{3} \mathrm{COOH}\right)$ dan air $\left(\mathrm{H}_{2} \mathrm{O}\right)$.

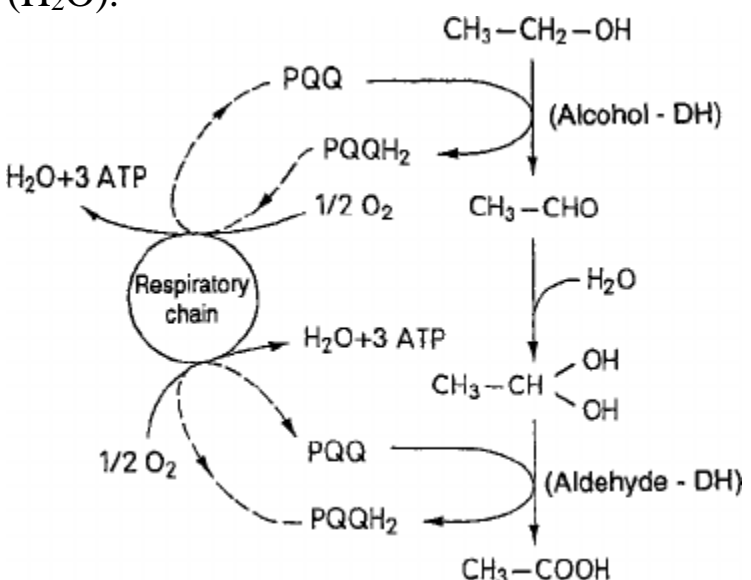

Gambar 7. Reaksi pembentukan asam asetat dari etanol (Belitz, Grosch, \& Schieberle, 2009)

Setelah 9 hari alkohol aren sudah berbentuk cuka aren, adapun pengujian secara organoleptik dan pengukuran nilai $\mathrm{pH}$ cuka aren, bahwa cuka aren berwarna putih, beraroma khas cuka, rasanya masam serta nilai $\mathrm{pH}$-nya sebesar 4. Adapun cuka aren dapat dilihat pada gambar 8 .

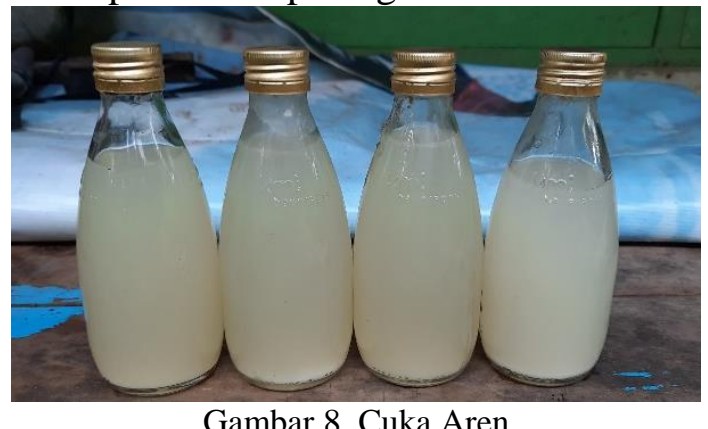

2. Pemanfaatan Cuka Aren Sebagai Pengobatan Tradisional Oleh Masyarakat Kampung Adat Kuta

Pemanfaatan cuka aren sebagai pengobatan tradisional oleh masyarakat Kampung Adat Kuta, bahwa cuka aren dimanfaatkan sebagai obat tradisional yang pemakaiannya dibagi menjadi dua bentuk yakni sebagai obat dalam (obat konsumsi) dan obat luar.

a. Praktik Pemanfaatan Cuka Aren Sebagai Obat Dalam

Langkah-langkah pembuatan ramuan obat dalam dari cuka aren dilakukan dengan cukup sederhana, yakni: 
- Botol yang berisi cuka aren dikocokkocok terlebih dahulu layaknya obat sirup, dengan tujuan supaya endapan dari cuka aren yang berwarna putih tercampur rata dengan larutan cukanya, mereka percaya bahwa pada endapan cuka aren terkandung senyawa obat. Sama halnya seperti pada cuka apel, endapannya disebut "mother of vinegar" yang merupakan biang dari cuka apel dan mengandung senyawasenyawa bioaktif didalamnya (Andyani, 2019).

- Cuka aren dituangkan ke dalam gelas sebanyak $1 / 4$ gelas.

- Ditambahkan air panas hingga satu gelas penuh, dengan tujuan untuk mengurangi rasa masam dari cuka aren serta memberikan rasa hangat ketika dikonsumsi.

- Setelah larutan cuka aren bercampur dengan air, maka cuka siap dikonsumsi.

Adapun praktik pengobatan konsumsi cuka aren oleh masyarakat Kampung Adat Kuta dapat dilihat pada gambar 9.

Penyakit yang dipercaya oleh masyarakat Kampung Adat Kuta yang dapat disembuhkan melalui konsumsi cuka aren yakni diabetes, liver dan asam lambung. Sayangnya, belum ada penelitian secara khusus cuka aren dapat dijadikan sebagai obat penyakit-penyakit tersebut. Namun, cuka-cuka nabati lain sudah cukup banyak dipublikasikan seperti:

- Cuka nabati sebagai obat diabetes

Cuka beras putih memiliki efek antidiabetik dalam mengontrol kadar gula darah, memperbaiki defisiensi insulin, perlindungan sel beta dan hepatosit pada tikus diabetes yang diinduksi menggunakan streptozotocin (Gu et al., 2012). Cuka apel dan cuka salak mampu menurunkan kadar glukosa darah karena kandungan asam asetatnya, aktivitas antioksidannya juga diduga berperan dalam memperbaiki sekresi insulin(Zubaidah \& Nuril F, 2015). Cuka buah mangrove pidada putih (Sonneratia alba) dapat menurunkan kadar gula darah pada tikus wistar hiperglikemia yang setara dengan obat oral sintesis yakni glibenklamid (Hardoko, Sasmito, \& Fitriani, 2020).

- Cuka nabati sebagai obat liver

Cuka nipah (Nypa fruticans) selama 14 hari secara terus menerus dapat memulihkan kerusakan hati yang disebabkan oleh parasetamol, karena cuka nipah mengandung asam polifenol seperti asam galat dan asam protocatechuic yang memberikan efek antioksidan dan antiinflamasi (Beh et al., 2016). Selain itu, pemberian cuka beras putih dapat memperbaiki kerusakan pada hati tikus diabetes, yakni penipisan glikogen serta penumpukan lemak pada hati tikus diabetes (Gu et al., 2012).

- Cuka nabati sebagai obat asam lambung

Ampas cuka apel "the mother" kaya akan probiotik atau bakteri-bakteri baik yang berperan dalam kesehatan saluran cerna, seperti mencegah terjadinya sembelit yang parah, gangguan asam lambung dan maag. Namun, kadar asam cuka yang tinggi dapat memperparah kondisi maag dan menyebabkan mual, sehingga tidak disarankan untuk meminumnya tanpa dilarutkan terlebih dahulu ke dalam air (Joseph \& Savitri, 2020).

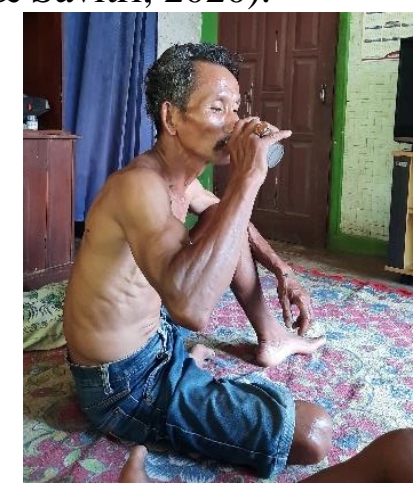

Gambar 9. Praktik pengobatan konsumsi cuka aren oleh masyarakat Kampung Adat Kuta

b. Praktik Pemanfaatan Cuka Aren Sebagai Obat Luar

Pembuatan ramuan obat luar dari cuka aren dilakukan dengan penambahan bahan lain yakni tanaman buntiris atau 
cocor bebek (Kalanchoe pinnata), dapat dilihat pada gambar 10 .

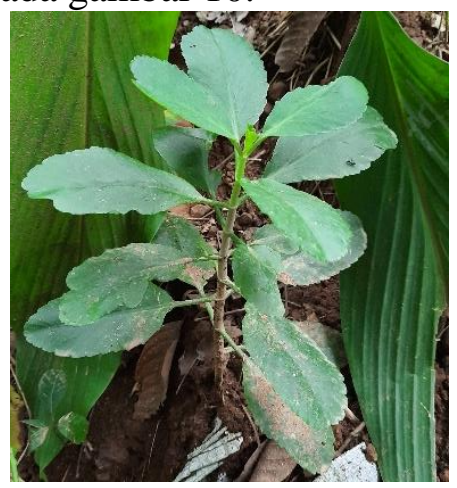

Gambar 10. buntiris atau cocor bebek (Kalanchoe pinnata)

Langkah-langkah pembuatan ramuan obat luar dari cuka aren, sebagai berikut:

- Cuci beberapa helai daun buntiris, lalu diremas-remas dan masukan pada wadah.

- Tambahkan cuka aren dan air panas, dengan perbandingan 1:1 ke dalam wadah yang berisi remasan daun buntiris. Tujuan penambahan air panas supaya ramuannya hangat ketika dibalurkan atau dikompreskan pada tubuh yang sakit.

- Aduk ramuan hingga rata, hingga siap digunakan.

Adapun praktik pengobatan luar dengan cara kompres atau pembaluran cuka aren oleh masyarakat Kampung Adat Kuta dapat dilihat pada gambar 11 .

Penyakit yang dipercaya oleh masyarakat Kampung Adat Kuta yang dapat disembuhkan melalui kompres maupun pembaluran cuka aren cuka aren yakni demam, pegal-pegal dan luka. Sayangnya, belum ada penelitian secara khusus cuka aren dapat dijadikan sebagai obat penyakit-penyakit tersebut. Namun, cuka-cuka nabati lain sudah cukup banyak dipublikasikan seperti:

- Cuka nabati sebagai obat demam

Praktik kompres cuka aren dengan remasan daun buntiris yang dilakukan oleh Masyarakat Kampung Adat Kuta, hanya bertujuan untuk menurunkan panas tubuh bagi seseorang yang mengalami demam, bukan mengobati penyakit penyebab demam itu sendiri. Berdasarkan hasil penelitian yang dilakukan oleh Mohammed \& Ahmed, (2012) bahwa kompres tubuh menggunakan cuka lebih efektif dan lebih cepat dalam menurunkan suhu tubuh dibandingkan dengan air dingin. Adapun kandungan zat berupa flavonoid pada cocor bebek memberikan efek antipiretik yakni menurunkan suhu tubuh pada keadaan demam (Purwitasari, Yuliet, \& Ihwan, 2017; Rezani, Safira, Khalidah, Sholahuddin, \& Analita, 2020).

- Cuka nabati sebagai obat pegal-pegal

Campuran air nira, bawang merah dan bawang putih yang dikubur dan difermentasikan selama 3 bulan digunakan sebagai minyak oles untuk obat asam urat (Handayani, 2015). Sayangnya proses fermentasinya tidak dijelaskan secara detail, kemungkinan besar minyak oles tersebut hampir sama dengan cuka aren yang dibuat di Kampung Adat Kuta, karena cara pembuatannya sama yakni dengan cara dikuburkan. Adapun kandungan pada cocor bebek mampu meredakan pegal-pegal karena memiliki efek antiinflamasi (Rezani et al., 2020).

- Cuka nabati sebagai obat luka

Cuka apel memiliki aktivitas antimikroba terhadap luka bernanah pada anjing yang terinfeksi Staphylococcus aureus (Dimariwu et al., 2020). Adapun gel ekstrak etanol $96 \%$ daun cocor bebek yang mengandung plavonoid, saponin dan tanin dapat digunakan sebagai penyembuhan luka bakar (Zahra, Harsodjo WS, \& Maifritrianti, 2017).

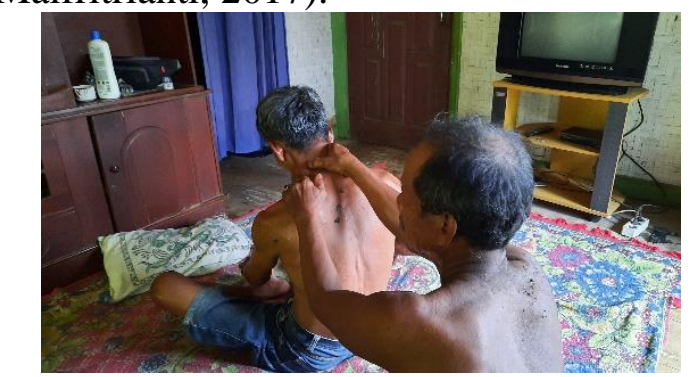

Gambar 11. Praktik pengobatan luar cuka aren oleh masyarakat Kampung Adat Kuta 


\section{SIMPULAN}

Berdasarkan hasil penelitian dapat disimpulkan bahwa pembuatan cuka aren di Kampung Adat Kuta meliputi proses pemuputan lodong, penyadapan air nira menggunakan raru, penyaringan air nira serta penyimpanan dan fermentasi air nira melalui proses fermentasi alkohol secara anaerob dan proses oksidasi berupa pembentukan senyawa asam asetat dari senyawa etanol. Adapun pemanfaatan cuka aren sebagai pengobatan tradisional bahwa cuka aren dimanfaatkan dalam pemakaiannya dibagi menjadi dua bentuk yakni sebagai obat dalam (obat konsumsi) yang dipercaya sebagai obat diabetes, liver dan asam lambung dan obat luar yang dipercaya sebagai obat demam, pegal-pegal dan luka.

\section{DAFTAR PUSTAKA}

Adeng, Alamsyah P., S., Herlinawati, L., Irma R., E., Masduki, A., Suhawan, W., \& Tirtayana. (2014). Kajian Kearifan Lokal di Kampung Kuta Kabupaten Ciamis. Bandung: Kementrian Pendidikan dan Kebudayaan Direktorat Jenderal Kebudayaan Balai Pelestarian Nilai Budaya Bandung.

Albuquerque, U. P., \& Alves, R. R. N. (2016). Introduction to Ethnobiology. In Introduction to Ethnobiology. https://doi.org/10.1007/978-3-31928155-1

Andyani, N. M. D. (2019). Perbedaan Zona Hambat Pertumbuhan Propionibacterium acnes Pada Berbagai Konsentrasi Cuka Apel (Apple Cider Vinegar) Secara In Vitro. Politeknik Kesehatan Denpasar.

Baharuddin, Syahidah, \& Yatni, N. (2009). Penentuan Mutu Cuka Nira Aren (Arenga pinnata) Berdasarkan SNI 014371-1996. Perennial, 5(1), 31. https://doi.org/10.24259/perennial.v5i 1.187
Beh, B. K., Mohamad, N. E., Yeap, S. K., Lim, K. L., Ho, W. Y., Yusof, H. M., ... Alitheen, N. B. (2016). Polyphenolic Profiles and the In vivo Antioxidant Effect of Nipa Vinegar on Paracetamol Induced Liver Damage. RSC Advances, 6(68), 63304-63313. https://doi.org/10.1039/c6ra13409b

Belitz, H. D., Grosch, W., \& Schieberle, P. (2009). Food Chemistry. Food Chemistry, (December 2008), 1-1070. https://doi.org/10.1007/978-3-54069934-7

Dimariwu, E. H., Tyasningsih, W., Rahmahani, J., Ernawati, R., Effendi, M. H., \& Handijatno, D. (2020). Aktivitas Antimikrob Cuka Apel terhadap Multidrug Resistance Staphylococcus aureus yang Diisolasi dari Luka Infeksi Anjing di Surabaya. 21(36), 292-299. https://doi.org/10.19087/jveteriner.202 0.21 .2 .292

Elfahmi, Woerdenbag, H. J., \& Kayser, O. (2014). Jamu: Indonesian Traditional Herbal Medicine Towards Rational Phytopharmacological Use. Journal of Herbal Medicine, 4(2), 51-73. https://doi.org/10.1016/j.hermed.2014. 01.002

Firmansyah, E. K., \& Putrisari, N. D. (2017). Sistem Religi dan Kepercayaan Masyarakat Kampung. Jurnal Pengabdian Kepada Masyarakat, 1, 236-243.

Gu, X., Zhao, H. L., Sui, Y., Guan, J., Chan, J. C. N., \& Tong, P. C. Y. (2012). White Rice Vinegar Improves Pancreatic Beta-cell Function and Fatty Liver in Streptozotocin-induced Diabetic Rats. Acta Diabetologica, 49(3), 185-191. https://doi.org/10.1007/s00592-0100184-6

Handayani, A. (2015). Pemanfaatan Tumbuhan Berkhasiat Obat Oleh Masyarakat Sekitar Cagar Alam 
Florea : Jurnal Biologi dan Pembelajarannya, 8(1), 2021, 1-11

This is an open access article under the CC-BY-SA license (https://creativecommons.org/licenses/by-sa/4.o/)

ISSN 2355-6102(print), ISSN 2502-0404(online)

DOI : 10.25273/florea.v8i1.8913

Gunung Simpang, Jawa Barat. 1(6), $1425-1432$.

https://doi.org/10.13057/psnmbi/m010 628

Hardoko, Sasmito, B. B., \& Fitriani, E. N. (2020). Studi Aktivitas Antidiabet Cuka Buah Mangrove Pedada (Sonneratia alba) Secara in Vivo. JFMR-Journal of Fisheries and Marine Research, 4(3), 399-407. https://doi.org/10.21776/ub.jfmr.2020. 004.03.13

Hasanah, H. (2017). Teknik-teknik Observasi (Sebuah Alternatif Metode Pengumpulan Data Kualitatif Ilmuilmu Sosial). At-Taqaddum, 8(1), 21. https://doi.org/10.21580/at.v8i1.1163

Irawan, B., Rahmayani, E., \& Iskandar, J. (2009). Studi Variasi, Pemanfaatan, Pengolahan dan Pengelolaan Aren di Desa Rancakalong, Kecamatan Rancakalong, Kabupaten Sumedang, Jawa Barat. Seminar Nasional Etnobotani IV, 1-25.

Joseph, N., \& Savitri, T. (2020). Cuka Apel: Manfaat Bagi Kesehatan, Efek Samping, dan Cara Pakainya. Retrieved March 3, 2021, from Hello Sehat, Kementrian Kesehatan Republik Indonesia website: https://hellosehat.com/nutrisi/faktagizi/manfaat-cuka-apel-efeksamping/\#gref

Kusmana, C., \& Hikmat, A. (2015). The Biodiversity of Flora in Indonesia. Journal of Natural Resources and Environmental Management, 5(2), 187-198.

https://doi.org/10.19081/jps1.5.2.187

Lempang, M. (2012). Pohon Aren dan Manfaat Produksinya. Info Tekhnis Eboni, 9, 37-54.

Mohammed, F. A., \& Ahmed, E. I. (2012). A Comparison of Vinegar Compresses vs. Cold Water \& Water with Vinegar for treating of Fever at Tropical Hospitals. International Journal of Nursing Science, 2(4), 38-46. https://doi.org/10.5923/j.nursing.2012
0204.03

Mufti, N., Bahar, E., \& Arisanti, D. (2017). Uji Daya Hambat Ekstrak Daun Sawo terhadap Bakteri Escherichia coli secara In Vitro. Jurnal Kesehatan Andalas, 6(2), 289-294. https://doi.org/10.25077/jka.v6i2.693

Naibaho, N. M., Ramadhan, A. F., Lisnawati, A., Rahman, M., \& Popang, E. G. (2017). Fermentasi Sistem Aerob dan Anaerob dalam Pembuatan Cuka Dari Nira Aren (Arenga pinnata). 14(01), 13-19.

Natawijaya, D., Suhartono, \& Undang. (2018). Analisis Rendemen Nira Kualitas Gula Aren (Arenga pinnata Merr.) di Kabupaten Tasikmalaya. Jurnal Agroforestri Indonesia, 1(1), 57-64.

https://doi.org/10.20886/jai.2018.1.1.5 7-64

Niemistö, J. (2014). Towards Sustainable and Efficient Biofuels Production: Use of Pervaporation in Product Recovery and Purification.

Nuryanti, S., Linda, R., \& Lovadi, I. (2015). Pemanfaatan Tumbuhan Arecaceae (Palem-Paleman) Oleh Masyarakat Dayak Randu Di Desa Batu Buil Kecamatan Belimbing Kabupaten Melawi. Protobiont, 4(1), 128-135.

Purwitasari, H., Yuliet, \& Ihwan. (2017). Efek Antipiretik Kombinasi Ekstrak Daun Cocor Bebek (Kalanchoe pinnata L.) dan Ekstrak Daun Tembelekan (Lantana camara L.) Terhadap Marmut (Cavia porcellus) Dengan Demam Yang Diinduksi Pepton. Jurnal Farmasi Galenika (Galenika Journal of Pharmacy), 3(1), 43-48.

Raudah, Zubaidah, T., \& Santoso, I. (2017). Efektivitas Sterilisasi Metode Panas Kering Pada Alat Medis Ruang Perawatan Luka Rumah Sakit dr. H. Soemarno Sostroatmodjo Kuala Kapuas. Jurnal Kesehatan Lingkungan, 14(1), 425-430. 
Florea : Jurnal Biologi dan Pembelajarannya, 8(1), 2021, 1-11

This is an open access article under the CC-BY-SA license (https://creativecommons.org/licenses/by-sa/4.o/)

ISSN 2355-6102(print), ISSN 2502-0404(online)

DOI : 10.25273/florea.v8i1.8913

Rezani, M. I., Safira, D., Khalidah, Sholahuddin, A., \& Analita, R. N. (2020). Tanaman Herbal Cocor Bebek (Kalanchoe pinnata (lam.) pers.) Sebagai Kompres Dingin Untuk Menurunkan Demam: Sebuah Tinjauan. Seminar Nasional Pendidikan Fisika, 65-70. Banjarmasin.

Rintelen, K. Von, Arida, E., \& Häuser, C. (2017). A Review of Biodiversityrelated Issues and Challenges in Megadiverse Indonesia and other Southeast Asian Countries. Research Ideas and Outcomes, 3, e20860. https://doi.org/10.3897/rio.3.e20860

Ryandita, F. R., Hernawati, D., \& Putra, R. R. (2020). Indigenous People Kampung Kuta Kabupaten Ciamis: Kajian Etnobotani Pemanfaatan Kelapa (Cocos nucifera L.). Florea: Jurnal Biologi Dan Pembelajarannya, $7(2)$, 54. https://doi.org/10.25273/florea.v7i2.78 86

Situmorang, T. S., \& Sihombing, E. S. R. (2018). Kajian Pemanfaatan Tumbuhan Obat Pada Masyarakat Suku Simalungun di Kecamatan Raya Desa Raya Bayu dan Raya Huluan Kabupaten Simalungun. Jurnal Biologi Lingkungan, Industri, Kesehatan, 4(2).
Sugiyono. (2016). Metode Penelitian Kuantitatif, Kualitatif, dan $R \& D$ (23rd ed.). Bandung: ALFABETA.

Sumendap, H. K., Pesik, M. U., \& Lagarense, B. E. S. (2015). Penggunaan Cuka Aren (Arenga Pinnata Merr) dalam Pengolahan Makanan Seafood: Studi Eksperimen. Jurnal Hospitality Dan Pariwisata, 2(1), 1-107. Retrieved from http://jurnal.polimdo.ac.id/index.php/p ariwisata/article/view/42/

Yudianti, I., Suprapti, \& Hupitoyo. (2015). Perbandingan Efektifitas Sterilisasi Panas Kering dan Desinfeksi Tingkat Tinggi Teknik Rebus terhadap Pertumbuhan Escherichia Coli. Jurnal Pendidikan Dan Pelayanan Kebidanan Indonesia, 2(1), 8-14. https://doi.org/10.24198/ijemc.v2i1.66

Zahra, E. H. R., Harsodjo WS, S., \& Maifritrianti. (2017). Aktivitas Penyembuhan Luka Bakar Fraksi Ekstrak Etanol 96\% Daun Cocor Bebek (Kalanchoe pinnata) [Lam.] Pers. Farmasains, 4(1), 1-7.

Zubaidah, E., \& Nuril F, I. (2015). Efek Cuka Apel dan Cuka Salak terhadap Penurunan Glukosa Darah dan Histopatologi Pankreas Tikus Wistar. Kedokteran Brawijaya, 28(4), 297301. 